Dzieje Najnowsze, Rocznik LIII - 2021, 4

PL ISSN 0419-8824

Joanna Karbarz-Wilińska

https://orcid.org/0000-0002-5009-6296

Oddziałowe Biuro Badań Historycznych

Instytutu Pamięci Narodowej w Gdańsku

\title{
Działalność biskupa stanisławowskiego Grzegorza Chomyszyna w latach dwóch wojen światowych. Analiza porównawcza
}

\begin{abstract}
Abstrakt: Główny cel artykułu stanowi przedstawienie losów greckokatolickiego duchownego Grzegorza Chomyszyna w czasie trwania dwóch najważniejszych konfliktów zbrojnych XX w. W chwili wybuchu I wojny światowej od dekady był już biskupem stanisławowskim, starając się wprowadzić zmiany w funkcjonowaniu Cerkwi greckokatolickiej i opowiadając się za jej latynizacja. Podczas II wojny światowej został kilkakrotnie aresztowany przez okupantów rosyjskich i niemieckich. Zmarł w grudniu 1945 r. wskutek brutalnych przesłuchań w więzieniu łukianowskim.
\end{abstract}

Słowa kluczowe: Grzegorz Chomyszyn, Galicja Wschodnia, Cerkiew greckokatolicka, I wojna światowa, II wojna światowa.

Abstract: The article's primary purpose is to present the fate of the Greek Catholic clergyman Hryhoriy Khomyshyn (1867-1945) during the two most important military conflicts of the twentieth century. At the outbreak of World War I, he had already been bishop of Stanyslaviv for a decade, trying to introduce changes in the functioning of the Greek Catholic Church and advocating its Latinization. During World War II, he was arrested several times by the Russian and German occupiers. He died in December 1945 due to brutal interrogations in Lukyanivska Prison.

Keyw ords: Hryhoriy Khomyshyn, Eastern Galicia, Greek Catholic Church, World War I, World War II. 
Grzegorz Chomyszyn przyszedł na świat w 1867 r. we wsi Hadyńkowce na Tarnopolszczyźnie. Był świadkiem największych konfliktów zbrojnych pierwszej połowy XX w.: I wojny światowej, wojny polsko-ukraińskiej (1918-1919) w Galicji Wschodniej oraz II wojny światowej. W latach 1917-1921 na ziemiach zajmowanych przez Ukraińców trwał także ich konflikt z bolszewikami. Wątek ten potraktowano jedynie jako wzmiankę, ponieważ działania te były prowadzone na obszarze Ukrainy Naddnieprzańskiej. W podobnym czasie toczyła się również wojna polsko-bolszewicka (1919-1921), której także nie poświęcono większej uwagi. W pracy skupiono się na terenie Galicji Wschodniej, z która związany był Grzegorz Chomyszyn i która przez ponad 120 lat, aż do momentu odzyskania przez Polskę niepodległości, pozostawała pod panowaniem Habsburgów.

Już od XIX w. rolę pośrednika między rządem a społeczeństwem ukraińskim zamieszkującym ten obszar odgrywało duchowieństwo greckokatolickie. W tym czasie posiadało ono także pewien zakres możliwości prowadzenia pracy społecznej i kulturalno-oświatowej, w tym podnoszenia świadomości narodowej Ukraińców ${ }^{1}$. Jego wpływ na społeczeństwo zaczą maleć na przełomie wieków XIX i XX na rzecz ukraińskiej świeckiej inteligencji, która zwróciła się w kierunku ruchu narodowego. Zmiany te obserwował Grzegorz Chomyszyn, obawiając się, że ruch ten może pochłonąc Cerkiew greckokatolicka. Od momentu, gdy w 1893 r. otrzymał święcenia kapłańskie, dążył do tego, aby koncentrowała się ona przede wszystkim na swoim posłannictwie duchowym $^{2}$. Niebezpieczeństwo dostrzegał zwłaszcza podczas I wojny światowej, kiedy mówił, że „Kościół i wiara zostały podporządkowane kwestii narodowej i traktuje się je jako środek do celu"3. Chciał, aby Cerkiew greckokatolicka oraz jej wierni kroczyli przejrzystą droga. Nie wahał się też napominać kleryków, których zachowanie nie przystawało do stanu duchownego ${ }^{4}$.

Ukraińcy już w połowie XIX w. liczyli na utworzenie z części ziem zajmowanych przez Habsburgów państwa ukraińskiego lub jego namiastki. Nadzieje te wzrosły wraz z perspektywą wybuchu ogólnoświatowego konfliktu zbrojnego, która zarysowała się na początku XX w. Protektora ukraińskiego ruchu niepodległościowego dopatrywano się w osobie Wilhelma Habsburga, jednak również rząd austriacki miał istotny cel w tym, by wspierać aspiracje

${ }^{1}$ O. Jehreszij, Jepyskop Hryhorij Chomyszyn. Portret relihijno-cerkownoho i hromadśko-politycznoho dijacza, Iwano-Frankiwśk 2006, s. 16.

2 J.P. Himka, Kościót greckokatolicki a procesy narodowotwórcze wśród Ukraińców w Galicji, „Znak” 1985, nr 4, s. 48.

${ }^{3}$ Ibidem.

${ }^{4}$ Przykładem może być m.in. sprawa ks. Pawła Kamińskiego, który otrzymał od biskupa kilka kar i nagan. W konsekwencji duchowny ten planował w 1911 r. zabójstwo Grzegorza Chomyszyna, ale próba się nie powiodła. Zob. Zamach na ks. biskupa Chomyszyna, „Kurier Stanisławowski" 1911, nr 1362, s. 1, http://anno.onb.ac.at/cgi-content/anno?aid=ksw\&datum= 19111015\&seite=1\&zoom=33 (dostęp: 29 X 2020). 
Ukraińców, chcąc ich wykorzystać do walki z siłami rosyjskimi. W tym samym celu zamierzał także udzielić wsparcia galicyjskim Polakom. Realizując swoje polityczne plany, rząd austro-węgierski lawirował więc między dążeniami niepodległościowymi dwóch narodów.

Wojska rosyjskie wkroczyły do Galicji Wschodniej w 1914 r., rozpoczynając okres krwawych walk na tym terenie. Były to starcia bratobójcze - Ukraińcy walczyli po obu stronach konfliktu (podobnie jak Polacy żyjący w różnych zaborach). Rosjanie planowali włączyć ten obszar w granice swojego państwa. Poddali ludność regularnym represjom i postanowili zlikwidować Cerkiew greckokatolicka, usiłując nakłonić jej wiernych do przejścia na prawosławie. Zamiarom tym chciał przeszkodzić metropolita Andrzej Szeptycki, którego wywieziono w głą Rosji. Podobnego losu unikną Grzegorz Chomyszyn.

Kiedy wybuchła I wojna światowa, od dekady był biskupem stanisławowskim. Diecezją kierował przez ponad 40 lat, pokonując szereg problemów związanych z jej organizacją. Pierwsze pojawiły się już wtedy, kiedy rozpoczynał posługę biskupia. W tym czasie na ziemiach zamieszkiwanych przez Ukraińców szerzył się ateizm i rosła liczba sekt, a ukraińska kultura i oświata nie były w dobrej kondycji. Pogarszała się również sytuacja materialna wiernych grekokatolików ${ }^{5}$. Pociagało to za sobą kłopoty finansowe diecezji, a duchowny wielokrotnie zmagał się $\mathrm{z}$ brakiem środków na jej utrzymanie. Jak podaje w listach pisanych z Workuty w 1953 r. bliski współpracownik Chomyszyna, Awksentij Bojczuk ${ }^{6}$, „był [on] najbiedniejszym naszym biskupem. [Miał do dyspozycji jedynie] stary pałac, który zakupiło miasto Stanisławów na użytek biskupstwa, oraz niewielki ogródek. Pensja za [czasów] austriackich wynosiła 2000 koron, i jej biskupowi nie wystarczało". Chomyszyn żył skromnie, a drogę z pałacu do katedry zazwyczaj pokonywał pieszo. Na wieść o tym namiestnik Galicji Andrzej Potocki podarował mu parę koni oraz swój powóz, biskup z nich jednak nie korzystał. Prezenty spieniężył, a środki przeznaczył na cele związane $\mathrm{z}$ działalnością duszpasterską

\footnotetext{
${ }^{5}$ N. Serdjuk, Jepyskop Hryhorij Chomyszyn mowoju materialiw slidstwa (za dokumentami Hałuzewoho Derżawnoho archiwu SB Ukrajiny), „Z Archiwiw WUCzK-GPU-NKWD-KGB” 2004, nr 1/2 (22/23), s. 452.

${ }^{6}$ Awksentij Bojczuk (1888-1971), kapłan Ukraińskiej Cerkwi Greckokatolickiej, działacz cerkiewny. W latach 1909-1913 student seminarium duchownego w Stanisławowie, a w latach 1916-1920 Uniwersytetu Wiedeńskiego. W latach 1920-1939 prorektor i rektor seminarium duchownego w Stanisławowie; w latach 1930-1936 redaktor pisma „Dobryj Pastyr”. W 1945 r. skazany na 10 lat ciężkiego więzienia i zesłany do obozu w Workucie. Zob. G. Chomyszyn, Dwa królestwa, red. I. Pełechatyj, W. Osadczy, tłum. M. Siudak, Kraków 2017, s. 134, 293.

${ }^{7}$ Pastyr dobryj. Hryhorij Chomyszyn, Jepyskop stanisławiwśkyj (25.03.1867 - 28.12.1945) u spohadach suczasnykiw, red. I. Pełechatyj, Iwano-Frankiwśk 2017, s. 64. Wspomniany pałac przypominał raczej stary dom, zbudowany w $1848 \mathrm{r}$. Miasto zakupiło go na potrzeby diecezji w 1888 r. Ibidem, s. 79.

8 Jak podano w gazecie „Hałyćkyj Korespondent”, biskup po swojemu zinterpretował „pański gest” i zdecydował się sprzedać konie, natomiast pieniądze rozdał podczas święta Jordanu
} 
Ważniejsze niż wsparcie finansowe okazało się doprecyzowanie kierunku, w jakim powinna się rozwijać Cerkiew greckokatolicka. Jeszcze w XIX w. w środowisku jej wiernych zrodziły się dwa przeciwstawne na to pomysły. Przedstawiciele pierwszego, zwanego rusofilskim, dążyli do jej zbliżenia z Cerkwią prawosławną i Rosją carską. Po drugiej stronie znalazła się grupa popierająca nurt narodowy ${ }^{9}$. I wojna światowa zastała więc Cerkiew greckokatolicką podzielona. Kiedy w 1914 r. Galicję Wschodnia zajęły wojska rosyjskie, wielu ukraińskich duchownych przeszło na prawosławie, zrywając jedność z Watykanem. W momencie, gdy te ziemie przejęły ponownie wojska austro-węgierskie, księża ci zostali internowani i usunięci ze stanowisk, a zwycięski okazał się ostatecznie kierunek narodowy, popierany przez Szeptyckiego ${ }^{10}$. Metropolita opowiedział się także za bizantynizacją Cerkwi greckokatolickiej. Z kolei Chomyszyn, przedstawiciel okcydentalizmu, zmierzał $\mathrm{w}$ kierunku jej latynizacji ${ }^{11}$ i z tego m.in. powodu przez Rosjan nazywany był „znanym mazepowcem” ${ }^{2}$. Określenie to nawiązywało do Iwana Mazepy, uznawanego przez nich za zdrajcę Rusi i prawosławia. Biskup stanisławowski rzeczywiście wielokrotnie wypowiadał się negatywnie na temat Rosji i krytykował dominujace $\mathrm{w}$ tym kraju wyznanie. Był świadomy tego, jak postrzegał go okupant i zdawał sobie sprawę z zagrożenia, jakie na niego czyhało w 1914 r. Z tego powodu wraz z wkroczeniem wojsk rosyjskich do Galicji Wschodniej opuścił Stanisławów ${ }^{13}$.

Podczas I wojny światowej Rosjanie okupowali miasto trzykrotnie. Pierwszy raz Stanisławów został przez nich zajęty 3 IX 1914 r. i odbity 20 II 1915 r. Od 4 III do 8 VI 1915 r. i od 11 IX 1916 r. do 24 VII 1917 r. ponownie znajdował się w rękach rosyjskich. Okupant Galicji Wschodniej zmieniał się jednak kilkakrotnie, co miało ogromne konsekwencje dla jej mieszkańców, wobec których każde władze stosowały szereg represji ${ }^{14}$. Zarówno działania

na schodach katedry. Zob. https://web.archive.org/web/20130120052647/http://gk-press. if.ua/node/8118 (dostęp: $6 \mathrm{~V}$ 2020). We wspomnieniach Bojczuka pozyskane środki miały zostać przeznaczone na zakup placu pod budowę przyszłego domu dla bezdomnych, który jednak nie powstał. Pastyr dobryj..., s. 64.

9 J. Karbarz-Wilińska, Dęby i burzany. Ukrainskie organizacje i partie zwiazane z biskupem stanistawowskim Grzegorzem Chomyszynem (1925-1939), Gdańsk-Warszawa 2020, s. 19-20.

10 A. Kinasz, Postawa duchowieństwa greckokatolickiej metropolii lwowskiej względem nowo powstałego państwa polskiego (1919-1924) w dokumentach Ministerstwa Spraw Zagranicznych II Rzeczypospolitej i konsystorza greckokatolickiego we Lwowie, w: Kościót unicki $w$ Rzeczypospolitej, red. W. Walczak, Białystok 2010, s. 63-64.

${ }^{11}$ Szerzej na temat obu kierunków zob. np.: S. Stępień, W poszukiwaniu tożsamości obrzqdkowej. Bizantynizacja a okcydentalizacja Kościoła greckokatolickiego w okresie międzywojennym, w: Polska - Ukraina 1000 lat sqsiedztwa, t. V: Miejsce i rola Kościoła greckokatolickiego $w$ Kościele powszechnym, red. S. Stępień, Przemyśl 2000, s. 87-102.

${ }_{12}$ O. Jehreszij, op. cit., s. 32.

${ }^{13}$ W. Osadczy, Święta Ruś. Rozwój i oddziaływanie idei prawosławia w Galicji, Lublin 2007, s. 669.

${ }^{14}$ Szerzej zob. S. Adamowycz, Socialno-ekonomiczne żyttja Stanisławowa $w$ period Perszoji switowoji wijny (1914-1918 pp.), w: Po stronie pamięci i dialogu... Stanisławów i ziemia 
władz rosyjskich, jak i austro-węgierskich oddaliły Ukraińców od celu, jakim było posiadanie własnego państwa ${ }^{15}$.

We wrześniu 1914 r. biskup stanisławowski znalazł schronienie w Wiedniu, jednak pomimo wyjazdu na początku wojny przez cały okres jej trwania był jedynym aktywnym hierarchą w Galicji ${ }^{16}$. W kwietniu 1915 r., po śmierci bpa Konstantego Czechowicza ${ }^{17}$, objął władzę naczelną nad metropolią halicka, w obrębie której znajdowały się archidiecezja lwowska, diecezja stanisławowska i diecezja tarnopolska. Do połowy stycznia 1915 r. sprawował również naczelną władzę hierarchiczną nad grekokatolikami pozostajacymi poza obrębem lwowskiej prowincji kościelnej ${ }^{18}$. W tym samym roku wraz z innymi greckokatolickimi duchownymi napisał do Benedykta XV list w obronie Ukraińców galicyjskich prześladowanych przez rosyjską administrację, zatytułowany $O$ losach $i$ stanowisku ukrainskiego duchowieństwa katolickiego, prosząc papieża o interwencję ${ }^{19}$.

Na początku maja 1915 r., po przełamaniu frontu rosyjskiego przez wojska austro-węgierskie i niemieckie oraz wyparciu Rosjan z Galicji, podją starania o wyjazd z Wiednia ${ }^{20}$. W innym liście z $1915 \mathrm{r}$., wydanym w czerwcu, $O$ dopustach Bożych w czasie wojny, pisał do duchowieństwa oraz wiernych: „Partia moskalofilska nie wyszła z duszy narodu, ale została sztucznie utworzona przez płatnych agentów rosyjskich i jest wspierana przez przeciwników dobra dla naszego narodu". Obwiniał tym samym przedstawicieli Ruskiej Partii Ludowej (Ruska Narodna Partija) o zdradę Ukraińców na rzecz Rosjan ${ }^{21}$ i ostrzegał swoich rodaków przed zgubnymi skutkami ich wpływów w Galicji Wschodniej. Podkreślał szczególnie, że ich celem jest uniemożliwić Ukraińcom utworzenie własnego państwa oraz włączyć zajmowane przez nich tereny do Rosji, a na miejsce wyznania greckokatolickiego wprowadzić prawosławie ${ }^{22}$.

W okresie I wojny światowej Chomyszyn sporo uwagi poświęcił m.in. Bukowinie. Sprawami administracyjnymi na tym terenie zają się od momentu

stanisławowska $w$ dobie przemian społecznych oraz narodowościowych XIX $i$ pierwszej potowy XX wieku, t. II: Gospodarka - Kultura - Religia, red. P. Hawrylyszyn, M. Kardas, A.A. Ostanek, Warszawa-Stanisławów 2017, s. 31.

15 A. Chojnowski, J.J. Bruski, Ukraina, Warszawa 2006, s. 26.

${ }^{16}$ W. Osadczy, op. cit., s. 588.

17 Konstantyn Czechowycz (1847-1915), ksiądz greckokatolicki, w latach 1896-1915 biskup przemyski, wspierający ukraiński ruch narodowy. W latach 1895-1914 poseł do Sejmu Krajowego Galicji. W 1915 r. aresztowany przez władze carskie podczas okupacji Przemyśla.

18 W. Osadczy, op. cit., s. 670.

${ }^{19}$ O. Jehreszij, op. cit., s. 32.

${ }^{20}$ Zamiar powrotu do Stanisławowa biskup stanisławowski ogłosił publicznie już dwa miesiace po swoim wyjeździe. Nie jest jednak pewne, czy udało mu się wtedy wrócić do swoich wiernych.

${ }^{21}$ Postanije pastyrśke Hryhorija Chomyszyna jepyskopa Stanistawiwśkoho do Duchowenśtwa $i$ wirnych swojeji jeparchiji o Dopustach Bożych w czasi wijny, Stanysławiw 1915, s. 4-5.

${ }^{22}$ Postanije pastyrśke Hryhorija Chomyszyna jepyskopa Stanistawiwśkoho do Duchowenśtwa i switśkoji intelihenciji o Podwyhach za dobri i swiati sprawy, Stanysławiw 1916, s. 18. 
objęcia godności biskupa. Mianował wówczas wielu duchownych i bronił interesów wiernych przed miejscową władza. Szczególnie ważny dla tamtejszych grekokatolików okazał się jego przyjazd do Bukowiny w 1915 r., kiedy wygłosił wiele znaczących kazań. Sam również był zadowolony ze stanu wiary i organizacji, jakie tam zasta ${ }^{23}$.

W tym czasie wdrażał wiele swoich pomysłów dotyczacych organizacji Cerkwi greckokatolickiej. W 1916 r. wprowadził w swojej diecezji kalendarz gregoriański, co logicznie uzasadniał ${ }^{24}$. Zrozumienie jego przekazu było jednak o tyle trudne, że nadal trwał spór między zwolennikami bizantynizacji Cerkwi greckokatolickiej a okcydentalistami. Pierwsi z wymienionych uważali, że Chomyszyn dąży do zlatynizowania Cerkwi greckokatolickiej, a w konsekwencji do podporządkowania jej obrządkowi rzymskokatolickiemu. Tymczasem biskup stanisławowski chciał ją maksymalnie odsunąć od rosyjskiego prawosławia, co wielokrotnie podkreślał. Ponadto, jak podaje Włodzimierz Osadczy, duchowny był przekonany, że „trzymając się kalendarza juliańskiego, grekokatolicy dawali kolejny powód do posądzeń o rusofilstwo, zwłaszcza w czasie wojny światowej" ${ }^{25}$. Biskup stanisławowski zastanawiał się również: „Jeśli nie mamy nic wspólnego z państwem rosyjskim, to dlaczego zachowujemy kalendarz rosyjski?"26. Co ważne, wprowadzenie nowego - gregoriańskiego - nie stanowiło, według niego, żadnego zagrożenia dla jedności narodu ukraińskiego. Twierdził nawet, że gdyby reforma się udała, „byłby to epokowy przełom w życiu naszego narodu"27. Pomimo argumentów Chomyszyna, przemawiających za rezygnacją z kalendarza juliańskiego, ukraińskie społeczeństwo galicyjskie negatywnie zareagowało na propozycję reformy ${ }^{28}$. Ostateczną decyzję w kwestii kalendarza gregoriańskiego podjęto podczas konferencji episkopatu greckokatolickiego 8 V 1925 r., rezygnując z pomysłu jego wprowadzenia i uznając go za „niebezpieczny eksperyment, który

${ }^{23}$ Do 1923 r. Bukowina podlegała pod diecezję stanisławowska. Zmiany nastapiły po włączeniu regionu do Rumunii. Zob. O. Rusnak, Chernivtsi and Suceava Deaneries of the Greek Catholic Church During the Pastoral Activities of Bishop H. Khomyshyn, „History Journal of Iurii Fedkovych Chernivtsi National University" 2017, nr 2, s. 84.

${ }^{24}$ J. Karbarz-Wilińska, Dęby i burzany..., s. 64-65.

25 W. Osadczy, op. cit., s. 589.

${ }^{26}$ Cyt. za: ibidem.

${ }^{27}$ Postanije pastyrśke Hryhorija Chomyszyna jepyskopa Stanistawiwśkoho do Duchowenśtwa $i$ wirnych swojeji jeparchiji o Pistannyctwi ukraijinśkoho naroda w Katotyćkij cerkwi, Stanysławiw 1916, s. 20, 22. Szerzej na temat reformy kalendarza zob. np.: O. Pawłyszyn, $Z$ istoriji wprowadżennja hryhorjanśkoho kalendaria w cerkowne żyttja ukrajinciw. Katendarna reforma jepyskopa Hryhorija Chomyszyna, „Ukrajina Moderna” 2002, nr 7; M. Strutyński, Myśl społeczno-polityczna Kościoła greckokatolickiego w II RP (1918-1939), Kraków 2019, s. 217-227.

${ }^{28}$ Przykładowo 27 II 1916 r. do biskupa zwróciła się delegacja ze stanisławowskiego powiatowego komitetu Ogólnej Rady Ukraińskiej (Zahalna Ukrajinśka Rada - ZUR) pod przewodnictwem Lwa Baczynśkiego z żądaniem jej odwołania. O. Jehreszij, op. cit., s. 35. 
wywołałby niepotrzebny niepokój w kraju...”29 W diecezji stanisławowskiej kalendarz gregoriański obowiązywał dwa lata. Sam Chomyszyn, choć podpisał dokument uznający kalendarz juliański za obowiązujący, trzymał się nowego stylu ${ }^{30}$.

$\mathrm{Na}$ początku 1917 r. na ziemiach rosyjskich, które również zajmowali Ukraińcy, doszło do obalenia caratu. To z kolei ośmieliło przedstawicieli ukraińskich partii i organizacji społecznych, zamieszkujących tamten obszar, do powołania w Kijowie 17 III 1917 r. Ukraińskiej Centralnej Rady (Ukrajinśka Centralna Rada - UCR). Latem tego roku UCR proklamowała autonomię Ukrainy (I Uniwersał), w listopadzie 1917 r. wydała III Uniwersał, tworząc Ukraińską Republikę Ludową (Ukrajinśka Narodna Respublika - UNR), a 25 I 1918 r. ogłosiła pełna niepodległość swojego państwa (IV Uniwersał ${ }^{31}$. Metropolita Szeptycki wraz z biskupami Chomyszynem i Jozafatem Kocyłowskim skierowali wówczas do swoich rodaków list, w którym otwarcie poparli idee państwowotwórcze. Apelowali przy tym do duchownych o jedność z narodem, podkreślając, jak ważne jest, by nikt nie stawiał przeszkód we wszechstronnym rozwoju życia narodowego i kulturalnego Ukraińców. Niemal równolegle próby utworzenia państwa podjęli rodacy biskupa stanisławowskiego w Galicji Wschodniej, również zyskując poparcie kleru greckokatolickiego. Sam Chomyszyn apelował do rządu austriackiego, aby ten dotrzymał warunków umowy z Brześcia Litewskiego z 9 II 1918 r., zgodnie z która Chełmszczyzna i Podlasie miały wejść do Ukraińskiej Republiki Ludowej ${ }^{32}$.

Wiosna 1918 r. stawało się jasne, kto poniesie klęskę w pierwszym światowym konflikcie. Jego zakończenie nie rozwiazało problemów polsko-ukraińskich w Galicji Wschodniej. Rozpad Austro-Węgier zaostrzył sytuację na tym terenie, jako że kwestia jego przynależności, czy to do narodu polskiego, czy do ukraińskiego, nie została ostatecznie rozstrzygnięta. Po obu stronach konfliktu wytworzyło się przekonanie, że Galicja Wschodnia należy wyłącznie do jednej z nich. To z kolei wywołało trwająca ponad rok wojnę polsko-ukraińska o ten obszar ${ }^{33}$.

W listopadzie 1918 r. Polska odzyskała niepodległość, Ukraińcy natomiast proklamowali we Lwowie Zachodnioukraińską Republikę Ludowa (Zachidno-Ukrajinśka Narodna Respublika - ZUNR). Poprzedziło to wyłonienie w nocy z 1 na 2 listopada w Stanisławowie Powiatowej Ukraińskiej Rady Narodowej, która w swojej odezwie do ludności powiatu informowała o przejęciu władzy

29 Ibidem, s. 39.

${ }^{30}$ O. Pawłyszyn, op. cit., s. 57.

31 Szerzej zob. A. Chojnowski, J.J. Bruski, op. cit., s. 27-32.

${ }^{32}$ O. Jehreszij, op. cit., s. 41-42.

${ }^{33}$ Szerzej na temat wojny polsko-ukraińskiej zob. R. Galuba, „Niech nas rozsqdzi miecz $i$ krew...” Konflikt polsko-ukraiński o Galicje Wschodnia w latach 1918-1919, Poznań 2004; M. Kozłowski, Zapomniana wojna. Walki o Lwów i Galicje Wschodnia 1918-1919, Bydgoszcz 1999. 
i wezwała do posłuszeństwa ${ }^{34}$. Niemała zasługę podczas przejęcia tego miasta przez Ukraińców mieli żołnierze austriackiego 95 i 58 pułku piechoty oraz niemieccy oficerowie, którzy jeszcze w nocy z 31 października na 1 listopada opanowali w nim główne obiekty. Co ważne, tzw. Czyn listopadowy w Stanisławowie odbył się bez rozlewu krwi, stanowiąc wyjątek w brutalnym konflikcie polsko-ukraińskim z lat 1918-1919.

Stanisławów odgrywał w tych latach ważną dla ukraińskiego ruchu narodowego rolę. Ze względu na jego położenie tranzytowe oraz potencjał demograficzny koncentrowało się w nim życie społeczne i ekonomiczne części Podkarpacia. W 1910 r. zamieszkiwało go 33,4 tys. osób, z czego najwięcej było Żydów i Polaków wyznania mojżeszowego (15,2 tys.). Polaków w Stanisławowie żyło 9 tys., a Ukraińców - 5,6 tys. Według spisu ludności z 1921 r. liczba mieszkańców wzrosła do 51,4 tys., w tym 23,2 tys. $(45,1 \%)$ Żydów, 18,3 tys. (35,5\%) Polaków, 8,6 tys. (16,7\%) Ukraińców i zaledwie 1,1 tys. (2,2\%) Niemców. Jak podaje Robert Grajny, w 1925 r. na czele listy mieszkańców Stanisławowa stanęli Polacy, a to za sprawą włączenia w granice miasta jego przedmieśćc ${ }^{35}$.

Nie w Stanisławowie, a we Lwowie stoczono jednak główne walki rozpoczętej w 1918 r. wojny polsko-ukraińskiej o Galicję Wschodnia ${ }^{36}$. Obie strony ponosiły w niej porażki, ale i odnosiły sukcesy. Obie opanowując dany teren, podkreślały swoje prawa do niego i dopuszczały się represji wobec ludności wrogiej narodowości. Ukraińcy objęli prześladowaniami m.in. osoby związane z Kościołem łacińskim ${ }^{37}$. Aresztowano 85 duchownych, a także przeprowadzono dziewięć nieudanych zamachów na życie księży rzymskokatolickich ${ }^{38}$.

22 XI 1918 r., kiedy Polacy zajęli Lwów, Szeptycki i biskup przemyski Kocyłowski zostali internowani. Obowiązki metropolity przeją Chomyszyn, który popierał ruchy Ukraińców w kierunku utworzenia własnego państwa. Zwrócił się wówczas do wiernych oraz duchowieństwa metropolii halickiej z listem pasterskim, nakazując duchownym wspominanie podczas nabożeństw prezydenta ZUNR Jewhena Petruszewycza, ukraińskiego rządu i wojska ${ }^{39}$. W kolejnym liście do duchowieństwa i wiernych, ze stycznia 1919 r., potwierdzał

${ }^{34}$ R. Grajny, Stosunek wtadz Zachodnio-Ukraińskiej Republiki Ludowej do spoteczności polskiej Stanisławowa w latach 1918-1919, w: Stanistawów i ziemia stanistawowska w II Rzeczypospolitej. Wojskowość - bezpieczeństwo - społeczeństwo - kultura, red. M. Kardas, A.A. Ostanek, P. Semków, Warszawa-Stanisławów 2017, s. 129.

${ }^{35}$ Ibidem, s. 130-131.

${ }^{36}$ M. Klimecki, Polsko-ukraińska wojna o Lwów i Galicję Wschodnia 1918-1919. Aspekty polityczne $i$ wojskowe, Warszawa 2000, s. 47-53.

${ }_{37}$ Powołując się na łacińskie źródła kościelne, Artur Kinasz podaje, że we wspomnianym okresie w Galicji Wschodniej, wskutek działań ukraińskich, zginęło sześciu księży łacińskich: ks. Wincenty Czyżewski, ks. Adam Hentschel, ks. Wawrzyniec Czarnik, ks. Wawrzyniec Raba, ks. Jan Dziuglewicz, ks. Jan Ruciński. A. Kinasz, op. cit., s. 64.

38 Ibidem, s. 65.

${ }^{39}$ O. Jehreszij, op. cit., s. 42. 
swoje stanowisko, zaznaczając jednak, że niezależna Ukraina powinna być zbudowana wyłącznie na zasadach wiary katolickiej. Pisał m.in.:

bez praw i prawd Bożych najwspanialsze nawet działania człowieka sa niczym innym jak tylko pustym dźwiękiem [...]. Te prawdy powinien mieć przed oczyma i naród ukraiński, który także walczy o status niezależnego narodu i na tym musi osadzić swoje państwo. A ma do tego wszelkie prawo. Jeśli na ziemi jest wystarczająco miejsca dla wszystkich narodów, to dlaczego nie miałoby wystarczyć go i dla narodu ukraińskiego $?^{40}$

W styczniu 1919 r. rząd ZUNR zmuszony został przenieść się do Stanisławowa, gdzie nadal odbywały się posiedzenia Rady Narodowej, w których udział brał biskup stanisławowski. 22 stycznia tego roku UNRada ogłosiła w Kijowie decyzję o połączeniu ZUNR i UNR. Duchowieństwo greckokatolickie ze Stanisławowa konsekwentnie wspierało te próby. W marcu 1919 r. „Wistnik Stanysławiwśkoji Jeparchiji” zamieścił ostrzeżenie bpa Chomyszyna, skierowane do greckokatolickiego duchowieństwa, pt. O niebezpieczeństwie dla narodu ukraińskiego. Duchowny po raz kolejny apelował o zjednoczenie wiernych na zasadach wiary i etyki chrześcijańskiej. Podkreślał również: „Nieszczęsny nasz naród! Ciężkie nieszczęścia i dopusty spadły na niego podczas wojny światowej, a teraz zawisło nad nim jeszcze większe niebezpieczeństwo. Bo nie tylko naród krwawił w wyniku walki o swoje istnienie, ale też grozi mu okrutna burza obecnego zła między samym narodem" ${ }^{41}$.

Wiosna pojawiły się spięcia między bpem Chomyszynem a działaczami ZUNR. Prawdopodobnie miały one podłoże konfliktu interesów. W połowie kwietnia 1919 r. uchwalono prawo dotyczące reformy rolnej, które przewidywało nacjonalizację cerkiewnych ziem, a więc podstawę materialnego funkcjonowania Cerkwi. Władyka ostro na nie zareagował ${ }^{42}$. Zwracał również uwagę na to, że rząd ZUNR nie poświęcił odpowiednio dużo uwagi zagadnieniom religijnym ${ }^{43}$. Pomimo to bp Chomyszyn na polecenie abpa Szeptyckiego zwołał w Stanisławowie zjazd działaczy religijnych, który odbył się 7-8 V 1919 r. Uczestniczyło w nim ponad 200 duchownych wspierających niezależność ZUNR ${ }^{44}$.

Latem 1919 r. ZUNR została zlikwidowana. Złagodzono także prześladowania wobec ludności polskiej i duchowieństwa rzymskokatolickiego

${ }^{40}$ Postanije pastyrśke Hryhorija Chomyszyna do Duchowenśtwa i wirnych jeparchiji Stanysławiwśkoji w perełomowu dobu istoriji ukraijinśkoho naroda torżestwa Jordanśkoho, Stanysławiw 1919, s. 8.

${ }^{41}$ O. Jehreszij, op. cit., s. 43.

${ }^{42}$ Ibidem, s. 44.

${ }^{43}$ Postanije pastyrśke Hryhorija Chomyszyna do Duchowenśtwa i wirnych jeparchiji Stanystawiwśkoji..., s. 11, 12, 14.

${ }^{44} \mathrm{Na}$ ten temat zob. np.: W. Marczuk, Myrotworcza misija Hreko-Katotyćkoji cerkwy u period ukrajinśko-polśkoji wijny 1918-1919 rr., w: Ukraincy w najnowszych dziejach Polski (1918-1989), t. I, red. R. Drozd, Słupsk-Warszawa 2000, s. 24-30. Zob. też: J. Karbarz-Wilińska, Dęby i burzany..., s. 53. 
w Galicji Wschodniej ${ }^{45}$. W czerwcu 1919 r. na konferencji paryskiej zdecydowano o przekazaniu tymczasowej administracji nad spornym terenem w ręce Polaków. Taki stan rzeczy miał obowiązywać przez 25 lat, a następnie planowano przeprowadzić plebiscyt wśród mieszkającej tam ludności. Jesienią cały region, po rzekę Zbrucz, zajmowały już wojska polskie ${ }^{46}$, kończąc wojnę polsko-ukraińska.

Sprawa Galicji Wschodniej powróciła w 1920 r., kiedy trwała już wojna z bolszewikami. Wówczas władze II RP oraz UNR zawarły tajne porozumienie w sprawie wspólnej walki przeciwko nim. Jeden z jej punktów stanowiło uznanie przez rząd Symona Petlury (UNR) granicy polsko-ukraińskiej na rzece Zbrucz, co oznaczało włączenie Galicji Wschodniej oraz Wołynia do Polski. Obiecująca współpraca polsko-ukraińska dobiegła końca w kwietniu 1921 r., kiedy przedstawiciele II RP podpisali traktat ryski z Rosją i Ukraina sowiecka, kończacy wojnę polsko-bolszewicką (1919-1921).

Oficjalnie sprawa przynależności Galicji Wschodniej rozstrzygnięta została dopiero w marcu 1923 r., kiedy Rada Ambasadorów uznała suwerenność Polski na tym terenie. Chociaż emigracyjny rząd ZUNR, przyjmując swoja porażkę, w 1919 r. przeniósł się do Wiednia i został rozwiązany, to jednak zaproponowane przez mocarstwa zamknięcie kwestii problematycznego terenu nie zakończyło sporów polsko-ukraińskich ${ }^{47}$.

Z obu opisanych konfliktów strona ukraińska wyszła przegrana, nadal pozostając bez własnego państwa, w przeciwieństwie do Polaków, którzy odzyskali niepodległość i mogli zająć się odbudową kraju i walką o jego ostateczne granice. Za swoje porażki Ukraińcy obwiniali wszystkich dookoła, znalazły się jednak osoby, które potrafiły chłodno spojrzeć na wydarzenia minionych dziesięcioleci i wytknąć Ukraińcom popełnione przez nich błędy. Jedną z nich był prof. Stepan Tomasziwśkyjj", który w 1922 r. porażki rodaków podsumował słowami: „Myśmy nie dojrzeli do swego państwa, jednak ogół społeczeństwa jest głęboko przekonany, że Lloyd George ogłosi wkrótce powstanie naszego państwa, a nas jutro porobi prezydentami, ministrami, posłami i obrzuci nas górami dobrego pieniądza..." ${ }^{49}$

Krytycznie działania Ukraińców oceniał również Chomyszyn. Zarówno podczas konfliktów zbrojnych, jak i okresów oficjalnego pokoju starał się

${ }^{45}$ R. Grajny, op. cit., s. 129.

${ }^{46}$ A. Kinasz, op. cit., s. 67.

47 Szerzej zob. R. Galuba, op. cit., s. 275.

${ }^{48}$ Stepan Tomasziwśkyj (1875-1930), ukraiński historyk, publicysta, polityk; od 1899 r. członek Towarzystwa Naukowego im. T. Szewczenki i jego przewodniczący w latach 19131915. Wykładowca Uniwersytetu Lwowskiego i Uniwersytetu Jagiellońskiego. W okresie międzywojennym ważna postać ukraińskiego obozu konserwatywnego; członek zarządu Ukraińskiej Organizacji Chrześcijańskiej (UChO). Encykłopedija ukrajinoznawstwa, red. W. Kubijowycz, t. IX, Lwiw 2000, s. 3236-3237.

${ }^{49}$ Piat' tystiw Tomasziwśkoho, „Nowa Zoria” 1931, nr 97, s. 9. 
chłodzić nastroje społeczne ${ }^{50}$. W obliczu pojawienia się różnych struktur ukraińskich, np. w 1920 r. Ukraińskiej Organizacji Wojskowej (Ukrajinśka Wijśkowa Orhanizacija - UWO), która stosowała w swoich działaniach terror i przemoc wobec Polaków, usiłował przekonywać rodaków, by pogodzili się z sytuacją i skupili się na odbudowie sił, opierając swoje życie na wartościach chrześcijańskich.

Pewne uspokojenie nastrojów miało przynieść powstanie ukraińskiej organizacji chrześcijańskiej. Pierwsze próby jej utworzenia podjęto we wczesnych latach dwudziestych, plan ten jednak się nie powiódł, ponieważ - jak pisze Mychajło Moskaluk - w tym samym czasie (1920 r.) bp Chomyszyn wprowadził w diecezji stanisławowskiej obowiązkowy celibat ${ }^{51}$. Pogłębiło to zdaniem autora konflikt w środowiskach, które uważały, że struktura taka powinna powstać, ale miały odmienne koncepcje na jej funkcjonowanie. W $1923 \mathrm{r}$. rektor seminarium duchownego we Lwowie o. Tytus Hałuszczynśkyj oraz Aleksander Barwiński usiłowali założyć Partię Chrześcijańsko-Narodowa (Chrystyjanśko-Nacionalna Partija - ChNP), jednak i ta próba się nie powio$\mathrm{dła}^{52}$. Dopiero w 1925 r. z sukcesem powołano do życia Ukraińska Organizację Chrześcijańską (Ukrajinśka Chrystyjanśka Orhanizacija - UChO), a jednym z inicjatorów przedsięwzięcia był Chomyszyn ${ }^{53}$.

Przez kolejne lata biskup starał się hamować wzajemną wrogość Polaków i Ukraińców w Galicji Wschodniej, wytykając obu stronom błędy, które przez lata popełniały one w swoich relacjach. W $1931 \mathrm{r}$. ogłosił list pasterski O politycznym położeniu narodu ukraińskiego $w$ państwie polskim, w którym przedstawił swój punkt widzenia na sytuację Ukraińców i przyczyny ich państwowotwórczych porażek. Dopatrywał się ich nie tyle w sile Polski, ale w politycznej niezręczności i nieporadności swoich rodaków. Jego narracja brzmiała konsekwentnie - przekonywał, że obie strony zawiniły i apelował, by Polacy i Ukraińcy doszli do porozumienia. Ich relacje pogarszały się

${ }^{50}$ Szerzej zob. np.: J. Karbarz-Wilińska, Koncepcja wzajemnej tolerancji $w$ myśli biskupa stanistawowskiego Hryhorija Chomyszyna. Przyczynek do relacji między katolikami obrzadków greckokatolickiego i rzymskokatolickiego w II Rzeczypospolitej, „Studia Historica Gedanensia" 2013, t. 4: Nietolerancja, s. 125-135.

${ }^{51}$ M. Moskaluk, Ukrajinśkyj chrystyjanśko-suspilnyj ruch u Hałyczyni. Ideołohija, instytualizacija, dijalnist' (kin. XIX - 30-ti rr.XX st.), Iwano-Frankiwśk 2018, s. 71. Decyzja dotycząca wprowadzenia powszechnego celibatu dla nowo wyświęcanych księży w metropolii lwowskiej została podjęta podczas konferencji episkopatu greckokatolickiego 20 VIII 1919 r., której przewodniczył metropolita Szeptycki. Pomimo to on sam podchodził do tej kwestii dosyć otwarcie i ostateczną decyzję wyboru celibatu lub jego nieprzestrzegania pozostawiał klerykom.

${ }^{52}$ Szerzej zob. ibidem, s. 72-73.

${ }^{53} \mathrm{~W}$ następnych latach $\mathrm{z}$ inicjatywy biskupa stanisławowskiego powstały również: $\mathrm{w} 1930 \mathrm{r}$. Ukraińska Katolicka Partia Ludowa (Ukrajinśka Katołyćka Narodna Partija - UKNP), a następnie w 1932 r. Ukraińska Odnowa Ludowa (Ukrajinśka Narodna Obnowa - UNO). Szerzej zob. J. Karbarz-Wilińska, Dęby i burzany..., passim. 
jednak, a przyczyniły się do tego coraz bardziej popularne w latach dwudziestych ruchy nacjonalistyczne. W 1929 r. powstała Organizacja Ukraińskich Nacjonalistów (Orhanizacija Ukrajinśkych Nacionalistiw - OUN), która podjęła wobec Polaków działania terrorystyczne. W 1930 r. władze polskie zareagowały na niszczenie polskiego mienia podczas akcji pacyfikacyjnej ${ }^{54}$. Zastosowanie zasady odpowiedzialności zbiorowej nie poprawiło stosunków między narodami. Surowy osąd władz polskich wydano m.in. podczas konferencji biskupów z udziałem metropolity Szeptyckiego, Kocyłowskiego oraz Chomyszyna. Jednocześnie skrytykowano wówczas działalność organizacji ukraińskich, które doprowadziły do eskalacji konfliktu ${ }^{55}$. Biskup Chomyszyn potępiał fakt, że pacyfikacja została skierowana nie tyle przeciwko zwolennikom akcji sabotażowych, co wobec niewinnej ludności ${ }^{56}$. Nazwał to „działaniem części czynnika szowinistycznego polskiej społeczności” ${ }^{7}$. Pisał m.in.: „rząd polski i polskie społeczeństwo nie powinno posądzać całego narodu ukraińskiego za przewinienia jednostek, albo jakiejś grupy, bo nie cały ukraiński naród solidaryzuje się z takim postępowaniem. Ogół ukraiński jest dobrej woli, jednakowoż domaga się spełnienia swoich słusznych postulatów i rząd polski powinien to wziać pod uwagę"58.

Nie zmieniło to jednak przekonania Chomyszyna o konieczności podejmowania prób łagodzenia napiętych nastrojów polsko-ukraińskich. Pomimo iż wielokrotnie był krytykowany przez swoich rodaków, a nawet oskarżany o działanie na rzecz wroga, starał się konsekwentnie tłumaczyć im, że do stworzenia podłoża dla państwa ukraińskiego należy porozumieć się z Polakami.

W momencie wybuchu II wojny światowej Chomyszyn przebywał w Stanisławowie. Kolejny światowy konflikt biskup przewidywał już na początku 1939 r., kiedy grekokatolicy obchodzili święta Bożego Narodzenia. Fakt ten znany jest m.in. z relacji prof. Antona Kniażynśkiego ${ }^{59}$, który w styczniu

${ }^{54}$ R. Wysocki, Liga Narodów wobec pacyfikacji Galicji Wschodniej w 1930 roku a polsko-ukraińska konfrontacja na arenie międzynarodowej, w: Ukraincy w najnowszych dziejach Polski..., s. 46-49.

${ }^{55}$ Zob. np.: Stowo do polśkoho hromadjanśtwa pro sabotażi, rewanżi i pacyfikaciju, „Nowa Zoria" 1930, s. 1-2.

${ }^{56}$ Pastyrśkyj tyst Hryhorija Chomyszyna do Wseczesnoho kłyra i wirnych Stanistawiwśkoji jeparchiji pro polityczne położennja ukrajinśkoho narodu w polśkij derżawi, Lwiw 1931, s. $11-12$.

${ }^{57}$ Ibidem.

58 G. Chomyszyn, Problem ukraiński, Warszawa 1933, s. 111-112.

59 Anton Kniażynśkyj (1893-1960), literaturoznawca, działacz społeczno-oświatowy, doktor filozofii; dyrektor gimnazjum w Kołomyi. Po I wojnie światowej pracownik kilku placówek naukowych (Jaworów, Drohobycz, Tarnopol, Sambor). W lutym 1928 r. jeden z inicjatorów powstania towarzystwa „Bojkiwszczyna”, od 1937 r. jeden z jego kierowników. Od 1944 r. w Wiedniu, tam w 1945 r. aresztowany przez Sowietów i skazany na 10 lat obozów. Od 1955 r. na wolności, wyjechał do Filadelfii, gdzie zmarł. W. Markus, Kniażynśkyj Antin, w: Encykłopedija Ukrajinśkoji Diaspory, red. W. Markus, t. I, Nju-Jork-Czikago 2009, s. 370-371. 
tego roku spotkał się z biskupem w Stanisławowie. Opisuje on, że władyka miło go powitał, kiedy jednak usłyszał życzenia świąteczne, spochmurniał i zwrócił się do obecnych na spotkaniu:

\begin{abstract}
Nie mówiłem jeszcze o tym nikomu, ale dziś powiem Wam, Ojcowie, i Panu, Panie profesorze, że przedwczoraj miałem widzenie, i wiem, że rok ten rozpocznie serię tragicznych lat naszej historii. Jesienią przybędą do nas bolszewicy. Wielu spośród naszych ludzi pójdzie na tułaczkę po dalekich obszarach okrutnego państwa sowieckiego, choć zło nie osiagnie jeszcze apogeum - będzie to jedynie niewielki wstęp do przyszłych tragedii ${ }^{60}$.
\end{abstract}

Jak podaje Kniażynśkyj we wspomnieniach, nikt z obecnych na spotkaniu nie chciał uwierzyć w słowa Chomyszyna ${ }^{61}$.

W połowie września 1939 r. na terytorium II Rzeczypospolitej wkroczyła Armia Czerwona, rozpoczynając masowe prześladowania ludności. Jedna z grup, która podlegała sowieckim represjom, było duchowieństwo greckokatolickie. Już w listopadzie Zarząd NKWD obwodu stanisławowskiego wszczął sprawę agenturalną pod nazwa „Dżuma”. Objęła ona rozpracowanie 20 duchownych biskupstwa stanisławowskiego, a do jej rozpoczęcia posłużyła informacja, że w latach 1932-1939 działała - z błędnie podaną nazwą organizacji - „Ukraińska nacionalna obnowa”62. Biskup stanisławowski, z którego inicjatywy zostały utworzone zarówno Ukraińska Odnowa Ludowa, ale także wcześniejsze - UChO i UKNP ${ }^{63}$, trafił pod nadzór władz sowieckich. Po raz pierwszy NKWD aresztowało go już w 1939 r., a jego mieszkanie przeszukano ${ }^{64}$. Duchowny został jednak szybko zwolniony i niewiele więcej wiemy na temat jego życia podczas okupacji sowieckiej do $1941 \mathrm{r}$. Skupił się on wówczas prawdopodobnie na duszpasterstwie, porzucając działalność społeczno-polityczną i kulturalno-oświatową ${ }^{65}$.

Niemniej, jak podaje Ołeh Jehreszij, 17 II 1941 r. władyka napisał list do znanego ukraińskiego działacza kulturalno-społecznego Kyryła Studynśkiego, w którym uskarżał się, że sowieckie służby specjalne śledzą jego oraz innych duchownych „i nie dają spokoju”. Pisał też, że ze strony władz „można spodziewać się represji” i prosił Studynśkiego, aby próbował temu zaradzić. Badacz nie natrafił na źródła potwierdzające tę pomoc, podaje

\footnotetext{
${ }^{60}$ A. Kniażynśkyj, Kyr Hryhorij Chomyszyn (Spohad pro Wtadyky-muczenyka Kyr Hryhorija Chomyszyna), w: Almanach Stanistawiwśkoji zemli. Zbirnyk materialiw do istoriji Stanistawowa $i$ Stanisławiwszczyny, t. II, red. M. Kłymyszyn, Nju-Jork-Paryż-Sidnej-Toronto 1985, s. 377-378.

${ }^{61}$ Rizdwiane proroctwo Hryhorija Chomyszyna, „Hałyćkyj Korespondent”, 20 I 2013, https:// web.archive.org/web/20130120052647/http://gk-press.if.ua/node/8118 (dostęp: 6 V 2020).

${ }^{62}$ N. Serdjuk, op. cit., s. 453-454.

${ }^{63}$ Czekiści określali je nawet „partiami biskupa Chomyszyna”.

${ }^{64}$ P. Melnyczuk, Wtadyka Hryhorij Chomyszyn. Patriot, misioner, muczenyk, Lwiw 1997, s. 286.

${ }^{65}$ O. Jehreszij, op. cit., s. 129, 137.
} 
jednak, że latem 1941 r., przed wyjściem z Galicji sowieckiej armii, służby specjalne podjęły nieudaną próbę otrucia Chomyszyna i jego pomocnika bpa Iwana Łatyszewśkiego ${ }^{66}$.

Niepokój towarzyszył biskupowi stanisławowskiemu przez cała okupację sowiecką i niemiecka. Na początku 1941 r. duchowny miał drugą wizję, w której ukazały mu się kolejne tragedie, których sprawcami mieli być Rosjanie oraz Niemcy. Przewidywał rozstrzeliwania ludności, ale informował też o „długich latach krwawych rządów bolszewików”. Przerażała go szczególnie wizja ponownego ich przyjścia na teren Galicji ${ }^{67}$. Zapowiadał, że poza znanym już okrucieństwem, którego doświadczyli jego rodacy, obejmą ich jeszcze wywózki do sowieckich obozów, w których wielu z nich umrze wskutek panujących tam ciężkich warunków. Co ciekawe, biskup informował, że on również zostanie zamordowany. Swojemu przyjacielowi mówił: „Ja sam też padnę ofiarą tego czasu i zginę w więzieniu, nie tutaj w Stanisławowie, ale gdzieś indziej"68.

22 VI 1941 r. rozpoczęła się wojna niemiecko-rosyjska, natomiast Prowid OUN ogłosił odnowienie państwa ukraińskiego. Utworzono je 30 VI 1941 r., powołujac rząd Jarosława Stećki. Chociaż zostało ono błyskawicznie rozwiąane przez Niemców, a wobec inicjatorów jego powołania zastosowano represje, to jednak sam fakt jego zaistnienia $\mathrm{w}$ warunkach wojennych zyskał poparcie ukraińskich środowisk, w tym również duchowieństwa greckokatolickiego. Błogosławieństwa tej inicjatywie udzielił też bp Chomyszyn. Ogłosił wówczas, że dziękuje „Najwyższemu z głębi serca za wysłuchanie naszych próśb i modlę się do Boga, aby państwo ukraińskie, wsparte na boskim prawie, zabezpieczył w szczęście, dobrobyt i spokojne życie [dla] wszystkich obywateli ziemi ukraińskiej bez względu na różnice wyznaniowe, narodowe i społeczne" (Stanisławów, 6 VII 1941 r. $)^{69}$. W 1945 r. podczas przesłuchania przez sowieckiego śledczego potwierdził, że popierał utworzenie państwa ukraińskiego, a w $1941 \mathrm{r}$. wierzył w szczerość obietnic niemieckiego dowództwa i w to, że sprzyjało ono idei stworzenia niezależnej Ukrainy ${ }^{70}$. W październiku $1941 \mathrm{r}$. wydał list pasterski, w którym przekonywał, że naród ukraiński może przetrwać wyłącznie, kiedy się skonsoliduje, a swoje działania oprze na wartościach chrześcijańskich ${ }^{71}$.

W lutym 1942 r. biskup stanisławowski został aresztowany przez gestapo. Obwiniono go o to, że wysyłał swoich ludzi do Kamieńca Podolskiego w celu „agitowania tamtejszej ludności”. Zarzuty te nie potwierdziły się, a Chomyszyn

${ }^{66}$ Ibidem, s. 129.

${ }_{67}$ Pierwsza okupacja sowiecka Galicji Wschodniej miała miejsce w latach 1939-1941. Od lipca 1941 do 1944 r. na tereny te wkroczyły wojska niemieckie. W lipcu 1944 r. ponownie znalazły się one pod okupacją sowiecka, a następnie włączono je do ZSRS.

${ }^{68}$ A. Kniażynśkyj, op. cit., s. 378.

${ }^{69}$ O. Jehreszij, op. cit., s. 129.

${ }^{70}$ Hałuzewyj Derżawnyj Archiw Służby Bezpeky Ukrajiny (dalej: HDA SBU), f. 6, spr. 75142-FP, t. I, k. 40, 71.

${ }^{71}$ O. Jehreszij, op. cit., s. 130. 
został zwolniony. Dodatkowo, jak podawał sam duchowny podczas zeznań w kwietniu 1945 r., jeden z gestapowców przeprosił go za ten incydent ${ }^{72}$.

W 1943 r. powstała formacja zbrojna utworzona przez frakcję banderowską OUN, pod nazwą Ukraińska Powstańcza Armia (Ukrajinśka Powstanśka Armija - UPA). Operowała ona głównie na terenach Wołynia oraz Galicji Wschodniej. Biskup stanisławowski nie popierał jej działalności. Można to wywnioskować chociażby na podstawie ogłaszanych przez niego przez lata apeli, aby w swoim postępowaniu opierać się na wartościach chrześcijańskich, z którymi działania OUN i UPA pozostawały w sprzeczności. Zawsze krytykował i potępiał wszelkie akty agresji wobec niewinnej ludności. 8 XI $1943 \mathrm{r}$. pisał w tej sprawie do metropolity Szeptyckiego, nalegajac na stworzenie listu pasterskiego wszystkich biskupów Cerkwi greckokatolickiej z powodu „upadku morale w naszym narodzie”. Chomyszyn podkreślał, że potępia „działania podziemne wszelkich nieodpowiedzialnych czynników”, stwierdzając, że „pod przykrywką walk podziemnych wytworzył się również formalny bandytyzm, a w ślad za tym anarchia"73. Potwierdzał to w 1945 r. podczas przesłuchań przez NKWD. Mówił także wówczas, że nawoływał do szukania legalnych dróg do stworzenia państwa ukraińskiego i piętnował wszelkie „ostre formy OUN w walce przeciwko Związkowi Sowieckiemu i polskiej ludności”"

Od lata 1943 r. Rosjanie zyskiwali przewage w zmaganiach II wojny światowej. Przełom w niej przyniosło ich zwycięstwo nad Niemcami w bitwie pod Stalingradem. Już na początku tego roku Niemcy zdecydowały się na utworzenie armii złożonej z Ukraińców. Wiosną powstała 14 Dywizja Waffen SS-Galizien (14 Dywizja Grenadierów SS - 1 ukraińska), którą licznie zasilili ukraińscy ochotnicy z Galicji Wschodniej ${ }^{75}$. Latem 1943 r. do bpa Chomyszyna zwrócił się niemiecki starosta Heinz Albrecht z nakazem skierowania specjalnej odezwy do duchownych diecezji, by ci wzywali wiernych do wstępowania w szeregi dywizji SS „Galicja”76. Chomyszyn spełnił polecenie, jednak, jak zeznawał w 1945 r., zabronił podległym mu duchownym dołączać do niej: „Niektórzy duchowni, około 5-6, dobrowolnie zapisało się do dywizji «Hałyczyna» i pytali mnie o zgodę na porzucenie służby w Cerkwi. Ja im na to nie pozwoliłem, na co dałem odpowiedź pisemna" 77 .

W lipcu 1944 r. na terytorium Galicji Wschodniej ponownie wkroczyły wojska sowieckie. Stanisławów został zajęty 27 lipca tego $\mathrm{roku}^{78}$. Przewidując rozwój wypadków, wielu galicyjskich Ukraińców podjęło wcześniej decyzję

\footnotetext{
${ }^{72}$ HDA SBU, f. 6, spr. 75142-FP, t. I, k. 41-42v.

${ }^{73}$ F. 201, op. 4v, spr. 1323, k. 22, cyt. za: O. Jehreszij, op. cit., s. 132.

${ }^{74}$ HDA SBU, f. 6, spr. 75142-FP, t. I, k. 108.

75 Szerzej zob. G. Motyka, Dywizja SS „Galizien” (,Hałyczyna”), „Pamięć i Sprawiedliwość” 2002, nr 1, s. 109-119.

${ }^{76}$ HDA SBU, f. 6, spr. 75142-FP, t. I, k. 46.

${ }^{77}$ Ibidem, k. 47.

${ }^{78}$ O. Jehreszij, op. cit., s. 133.
} 
o emigracji do Europy Zachodniej oraz Ameryki. Biskup Chomyszyn nie pochwalał takiego wyboru i jeszcze w styczniu $1944 \mathrm{r}$. napisał list do duchowieństwa swojej diecezji. Podkreślał w nim: „Nie sztuka odgrywać rolę wielkich patriotów, sypać mogiły, wygłaszać głębokie patriotyczne przemowy, a przy grożącym niebezpieczeństwie uciekać niczym zając z kapusty. Dlatego pod surową odpowiedzialnością zabraniam wyjazdów za granicę diecezji w razie inwazji bolszewików"79. Chomyszyn uważał, że duchowni w każdych okolicznościach powinni pozostać z wiernymi. Szczególnie ważne było to w sytuacji, gdy jeden z głównych celów władz rosyjskich stanowiło zlikwidowanie Cerkwi greckokatolickiej.

On sam - jak przewidywał - padł ofiara sowieckich represji. Został aresztowany w kwietniu 1945 r., kiedy Sowieci zlikwidowali biskupstwo stanisławowskie $^{80}$. Plany tych działań pojawiły się już 26 marca $^{81}$. Zatrzymanie duchownego miało prawdopodobnie brutalny przebieg ${ }^{82}$. Został oskarżony m.in. o kolaborację z Niemcami, a także zachęcanie młodzieży do wstępowania do OUN-UPA ${ }^{83}$. Drugi z zarzutów był zupełnie bezpodstawny, gdyż przez cały okres swojej posługi Chomyszyn sprzeciwiał się głoszonemu przez te organizacje nacjonalizmowi i stosowanemu przez nie terrorowi. Zarzucono mu ponadto propagandę

${ }^{79}$ F. 201, op. 4v, spr. 1323, k. 1-29, cyt. za: O. Jehreszij, op. cit., s. 134.

${ }^{80} \mathrm{~W}$ tym czasie aresztowani zostali również m.in. arcybiskup greckokatolicki, metropolita lwowski Josyf Slipyj, a także biskupi Mykyta Budka, Mykoła Czarnećkyj i Iwan Łatyszewśkyj. T. Wolsza, Za żelazna kurtyna. Europa Środkowo-Wschodnia, Zwiqzek Sowiecki $i$ Józef Stalin $w$ opiniach polskiej emigracji politycznej $w$ Wielkiej Brytanii 1944/1945-1953, Warszawa 2005, s. 203. Władze sowieckie dokonując zaboru wschodnich ziem Polski, za jeden z głównych celów obrały zlikwidowanie katolicyzmu. W latach 1945-1946 zniszczyły 11 diecezji obrządków: greckokatolickiego, rzymskokatolickiego oraz ormiańskokatolickiego, dokonały aresztowań kilkunastu biskupów, a ok. 4 tys. księży zostało wywiezionych w głąb Rosji. Idem, Rzad RP na obczyźnie wobec wschodniej granicy Polski (lipiec 1945 - luty 1951 roku), „Polska 1944/45-1989. Studia i Materiały” 1996, t. II, s. 86. Szerzej na temat likwidacji Kościoła unickiego przez Sowietów od kwietnia 1945 r. do kwietnia 1946 r. zob. np.: idem, Za żelazna kurtyna..., s. 202-209.

${ }^{81}$ HDA SBU, f. 6, spr. 75142-FP, t. I, k. 1a-2. W Wydzielonym Archiwum Służby Bezpieczeństwa Ukrainy (Hałuzewyj Derżawnyj Archiw Służby Bezpeky Ukrajiny - HDA SBU) znajdują się dwa tomy sprawy poświęconej aresztowaniom duchowieństwa greckokatolickiego w kwietniu 1945 r. Dokumentacja dotycząca bpa Chomyszyna zgromadzona została w t. I (są to m.in.: decyzja o aresztowaniu, wykaz rzeczy znalezionych u biskupa podczas przeszukania jego mieszkania czy ponad 30 protokołów przesłuchań duchownego) i częściowo w t. II (np. akt zgonu). Tom II zawiera materiały poświęcone aresztowaniu i przesłuchaniom głównie bpa Łatyszewśkiego, ale również odnajdziemy w nim protokoły przesłuchań Bojczuka (rok 1945) oraz wyciagi z przesłuchań innych duchownych greckokatolickich i członków UNO (lata 1939 i 1945). Materiały dotyczą głównie okresu II wojny światowej, ale w zeznaniach przesłuchiwanych pojawiają się również fakty z lat dwudziestych i trzydziestych XX w. Co istotne, w większości dokumentów poświęconych bpowi Chomyszynowi błędnie wpisano datę jego urodzin (zamiast 1867 pojawiaja się: 1863 lub 1868) i tylko w nielicznych jest ona odręcznie poprawiona.

${ }^{82}$ Opis jego zatrzymania zamieścił w swojej publikacji np. Petro Melnyczuk. Wspominał m.in., że biskup sprawiał wrażenie „udręczonego człowieka”, a na jego twarzy widać było krew. Zob. P. Melnyczuk, op. cit., s. 286.

${ }^{83}$ HDA SBU, f. 6, spr. 75142-FP, t. I, k. 1a-2. 
antyradziecka, szpiegowanie na korzyść Watykanu, prowadzenie propolskiej polityki, wzmocnienie pozycji Cerkwi unickiej na ziemiach zachodnioukrainskich oraz wspieranie rozpowszechniania katolicyzmu na Wschodzie ${ }^{84}$.

Przesłuchania w więzieniu łukianowskim (zatem „gdzieś indziej”, zgodnie z jego wizją z 1941 r.), rozpoczęte 21 kwietnia, a więc 10 dni po aresztowaniu, trwały do 11 IX 1945 r. Sporządzono z nich 36 protokołów ${ }^{85}$. Pierwsze miało charakter ogólny: pytano o biografię, stosunek do władzy sowieckiej itd. ${ }^{86}$ Kolejne przebiegały już w sposób brutalny. Biskup pozostawał jednak nieugięty, jeśli chodzi o swoje przekonania i stosunek do nowych władz. Według relacji Kniażynśkiego na jedno z pytań śledczego, zadane podczas ostatniego przesłuchania: „Jeśli byśmy was wypuścili na wolność, to co byście zrobili?”, bp Chomyszyn miał odpowiedzieć: „To samo co do tej pory! Będę bronił przed wami, bo jestem sługa Chrystusa, a wy Jego wrogami"87.

Wskutek wyczerpujących przesłuchań i trudnych warunków, w jakich był przetrzymywany, stan zdrowia blisko osiemdziesięcioletniego Chomyszyna pogarszał się. 21 grudnia przewieziono go do więziennego szpitala. Zmarł nagle kilka dni później - 28 XII 1945 r.

Biskup stanisławowski był świadkiem dwóch wojen światowych i sam doświadczył ich skutków. Podczas trwania obu konfliktów Ukraińcy pozostawali $\mathrm{w}$ pewnym sensie na podobnym etapie swojej drogi do uzyskania własnego państwa, a sam duchowny miał w obu okresach zbliżone zadania do wykonania. Wspierał budowanie państwowości ukraińskiej, a jednocześnie robił wszystko, aby proces ten odbywał się na zasadach chrześcijańskich, bez przemocy i terroru, szczególnie wobec niewinnej ludności. Konsekwentnie zabiegał też o zgodę między Ukraińcami i Polakami. Zadanie to utrudniał fakt, że niewiele osób, po obu stronach konfliktu, widziało szansę na jakiekolwiek wzajemne porozumienie.

Podczas I wojny światowej Chomyszyn mógł bardziej skupić się na rozwoju Cerkwi greckokatolickiej, podejmując próby pewnych zmian i skierowania jej w stronę okcydentalizacji. Choć nie był to dobry czas, to jednak dopiero II wojna światowa stała się dla biskupa stanisławowskiego prawdziwą walka o przetrwanie, która niestety przegrał.

Prześladowany i zamordowany przez Sowietów, Chomyszyn został beatyfikowany przez Jana Pawła II 27 VI 2001 r. we Lwowie. Wraz z biskupem stanisławowskim papież błogosławionymi ogłosił jeszcze 27 innych męczenników greckokatolickich. Pamięć Grzegorza Chomyszyna w marcu 2017 r., zatem w 150. rocznicę jego urodzin, uczcił także Sejm $\mathrm{RP}^{88}$.

\footnotetext{
${ }^{84}$ Ibidem; zob. też: ibidem, k. 61-62.

${ }^{85}$ N. Serdjuk, op. cit., s. 455.

${ }^{86}$ HDA SBU, f. 6, spr. 75142-FP, t. I, k. 1a-2.

${ }^{87}$ A. Kniażynśkyj, op. cit., s. 378.

${ }_{88}$ Zob. Aneks.
} 


\section{Streszczenie}

Grzegorz Chomyszyn związał życie z Galicją Wschodnia, obejmując w 1904 r. godność biskupa stanisławowskiego. Po wybuchu I wojny światowej był zmuszony wyjechać do Wiednia, szybko podją jednak starania, by wrócić do Stanisławowa, gdzie dalej pełnił posługę kapłańską. W tym czasie musiał się zmierzyć ze sporem dotyczącym kierunku przyszłego rozwoju Cerkwi grekokatolickiej. Przez całą I wojnę światową był jedynym jej czynnym hierarchą w Galicji, występując w obronie zamieszkujących ją Ukraińców, szykanowanych m.in. przez administrację rosyjska. Wprowadził też kalendarz gregoriański, który obowiązywał w diecezji stanisławowskiej przez dwa lata. Kiedy Ukraińcy podejmowali próby stworzenia własnego państwa, wspierał ich w tych działaniach, podkreślając jednak, że powinny się one opierać na zasadach chrześcijańskich, dlatego stał się inicjatorem utworzenia kilku organizacji i partii o tym profilu. Podobne postulaty wysuwał również w latach dwudziestych i trzydziestych XX w., kiedy zaczęły się formować ukraińskie organizacje nacjonalistyczne (UWO, OUN, UPA), posługujące się w swojej działalności terrorem i przemoca. Biskup stanisławowski wielokrotnie podejmował próby łagodzenia napiętych nastrojów polsko-ukraińskich w Galicji Wschodniej. W momencie wybuchu II wojny światowej przebywał w Stanisławowie. Niemal równocześnie z wkroczeniem Armii Czerwonej na terytorium II Rzeczypospolitej padł ofiara prześladowań sowieckich i został na krótko aresztowany. Do $1941 \mathrm{r}$. skupił się głównie na działalności duszpasterskiej. Na początku 1942 r. został zatrzymany przez gestapo, ale również szybko zwolniony z aresztu. Koniec jego pracy nastapił wraz z powrotem wojsk sowieckich do Galicji Wschodniej (lipiec 1944 r.). W kwietniu 1945 r. duchowny znalazł się w więzieniu łukianowskim i kilka miesięcy później, wskutek wyczerpujaccych przesłuchań, zmarł.

\section{The Activity of Hryhoriy Khomyshyn, Bishop of Stanyslaviv, in the Years of Two World Wars: A Comparative Analysis}

Hryhoriy Khomyshyn, becoming Bishop of Stanyslaviv in 1904, devoted his life to Eastern Galicia. After the outbreak of World War I, he was forced to leave for Vienna but quickly made efforts to return to Stanyslaviv, where he continued to serve as a priest. At that time, he had to face a dispute concerning the direction of the future development of the Greek Catholic Church. Throughout World War I, he was the only active hierarch in Galicia, defending the Ukrainians living there who were persecuted by, i.a., the Russian administration. He also introduced the Gregorian calendar, which was used in the diocese of Stanyslaviv for two years. When Ukrainians tried to create their own state, he supported them, stressing that it should be based on Christian principles. He also put forward similar proposals in the 1920s and 1930s, when Ukrainian nationalist organisations (UVO, OUN, UPA) began to be formed, using terror and violence. The Bishop of Stanyslaviv tried to soothe tense Polish-Ukrainian sentiments in Eastern Galicia on many occasions. At the outbreak of World War II, he was in Stanyslaviv. Almost at the same time as the Red Army entered the territory of the Second Polish Republic, he fell victim to Soviet persecution and was briefly arrested. Until 1941 he concentrated mainly on pastoral work. At the beginning of 1942, he was detained by the Gestapo, but was also quickly released from custody. The end of his work did not come until the return of Soviet troops to Eastern Galicia (July 1944). In April 1945, the clergyman was imprisoned in Lukyanivska Prison and died a few months later due to exhausting interrogations. 


\title{
ANEKS
}

\section{Uchwała upamiętniająca bł. greckokatolickiego bp. Grzegorza Chomyszyna przyjęta przez Sejm RP w 150. rocznicę jego urodzin}

\author{
U C H W A Ł A \\ SE JMU RZECZYPOSPOLITE J POLSKIE J \\ $\mathrm{z}$ dnia 23 marca $2017 \mathrm{r}$. \\ w sprawie uczczenia pamięci błogosławionego biskupa \\ Grzegorza Chomyszyna w 150 . rocznice jego urodzin
}

Sejm Rzeczypospolitej Polskiej w 150. rocznicę urodzin błogosławionego biskupa Grzegorza Chomyszyna - greckokatolickiego ordynariusza stanisławowskiego, obywatela II Rzeczypospolitej Polskiej, męczennika reżimu komunistycznego, nieustajacego orędownika pojednania polsko-ukraińskiego składa hołd Prorokowi Ukrainy, który był niestrudzonym głosicielem wartości europejskich wyrastających z tradycji chrześcijaństwa i cywilizacji łacińskiej. Przestrzegał on swój naród przed zbrodniczymi ideologiami, nawołującymi do nienawiści i niszczenia wielowiekowego dorobku tradycji tolerancji wytworzonej na ziemiach I Rzeczypospolitej.

Postać błogosławionego biskupa powinna stać się symbolem polsko-ukraińskiego pojednania opartego na historycznym i duchowym dziedzictwie wspólnoty obu narodów bazującym na niepodważalnych fundamentach moralności i prawdy.

MARSZAEEK SEJMU

/ - / Marek Kuchciński

Źródło: http://orka.sejm.gov.pl/proc8.nsf/uchwaly/1402_u.htm (dostęp: 24 III 2021).

\section{Bibliografia}

Chojnowski A., Bruski J.J., Ukraina, Warszawa 2006.

Chomyszyn G., Dwa królestwa, red. I. Pełechatyj, W. Osadczy, tłum. M. Siudak, Kraków 2017. Chomyszyn G., Problem ukrainski, Warszawa 1933.

Galuba R., „Niech nas rozsadzi miecz i krew...” Konflikt polsko-ukraiński o Galicję Wschodnia w latach 1918-1919, Poznań 2004.

Grajny R., Stosunek władz Zachodnio-Ukraińskiej Republiki Ludowej do spoteczności polskiej Stanisławowa w latach 1918-1919, w: Stanisławów i ziemia stanistawowska w II Rzeczypospolitej. Wojskowość - bezpieczeństwo - spoteczeństwo - kultura, red. M. Kardas, A.A. Ostanek, P. Semków, Warszawa-Stanisławów 2017, s. 129-142. 
Himka J.P., Kościót greckokatolicki a procesy narodowotwórcze wśród Ukrainców w Galicji, „Znak” 1985, nr 4, s. 41-52.

Jehreszij O., Jepyskop Hryhorij Chomyszyn. Portret relihijno-cerkownoho i hromadśko-politycznoho dijacza, Iwano-Frankiwśk 2006.

Karbarz-Wilińska J., Dęby i burzany. Ukraińskie organizacje i partie zwiazane z biskupem stanisławowskim Grzegorzem Chomyszynem (1925-1939), Gdańsk-Warszawa 2020.

Karbarz-Wilińska J., Koncepcja wzajemnej tolerancji w myśli biskupa stanistawowskiego Hryhorija Chomyszyna. Przyczynek do relacji między katolikami obrzqdków greckokatolickiego i rzymskokatolickiego w II Rzeczypospolitej, „Studia Historica Gedanensia” 2013, t. IV: Nietolerancja, s. 125-135.

Klimecki M., Polsko-ukrainska wojna o Lwów i Galicję Wschodnia 1918-1919. Aspekty polityczne $i$ wojskowe, Warszawa 2000.

Kozłowski M., Zapomniana wojna. Walki o Lwów i Galicję Wschodnia 1918-1919, Bydgoszcz 1999.

Marczuk W., Myrotworcza misija Hreko-Katotyćkoji cerkwy u period ukrajinśko-polśkoji wijny 1918-1919 rr., w: Ukraincy w najnowszych dziejach Polski (1918-1989), t. I, red. R. Drozd, Słupsk-Warszawa 2000, s. 24-30.

Melnyczuk P., Wtadyka Hryhorij Chomyszyn. Patriot, misioner, muczenyk, Lwiw 1997.

Moskaluk M., Ukrajinśkyj chrystyjanśko-suspilnyj ruch u Hatyczyni. Ideołohija, instytualizacija, dijalnist' (kin. XIX - 30-ti rr.XX st.), Iwano-Frankiwśk 2018.

Osadczy W., Święta Ruś. Rozwój i oddziatywanie idei prawostawia w Galicji, Lublin 2007.

Pastyr dobryj. Hryhorij Chomyszyn, Jepyskop stanisławiwśkyj (25.03.1867 - 28.12.1945) u spohadach suczasnykiw, red. I. Pełechatyj, Iwano-Frankiwśk 2017.

Pastyrśkyj tyst Hryhorija Chomyszyna do Wseczesnoho ktyra i wirnych Stanistawiwśkoji jeparchiji pro polityczne położennja ukrajinśkoho narodu w polśkij derżawi, Lwiw 1931.

Serdjuk N., Jepyskop Hryhorij Chomyszyn mowoju materialiw slidstwa (za dokumentami Hałuzewoho Derżawnoho archiwu SB Ukrajiny), „Z Archiwiw WUCzK-GPU-NKWD-KGB” 2004, nr 1/2 (22/23), s. 451-480.

Strutyński M., Myśl społeczno-polityczna Kościoła greckokatolickiego w II RP (1918-1939), Kraków 2019.

Wolsza T., Rzad RP na obczyźnie wobec wschodniej granicy Polski (lipiec 1945 - luty 1951 roku), „Polska 1944/45-1989. Studia i Materiały” 1996, t. II, s. 81-92.

Wolsza T., Za żelazna kurtyna. Europa Środkowo-Wschodnia, Zwiazek Sowiecki i Józef Stalin w opiniach polskiej emigracji politycznej w Wielkiej Brytanii 1944/1945-1953, Warszawa 2005.

Wysocki R., Liga Narodów wobec pacyfikacji Galicji Wschodniej w 1930 roku a polsko-ukraińska konfrontacja na arenie międzynarodowej, w: Ukraincy w najnowszych dziejach Polski (1918-1989), t. I, red. R. Drozd, Słupsk-Warszawa 2000, s. 46-55.

Joanna Karbarz-Wilińska - dr, pracownik naukowy Oddziałowego Biura Badań Historycznych Instytutu Pamięci Narodowej w Gdańsku. Jej zainteresowania badawcze koncentrują się wokół historii Ukrainy oraz stosunków polsko-ukraińskich w XX w. E-mail: joanna.karbarz-wilinska@ipn.gov.pl.

Joanna Karbarz-Wilińska - PhD, researcher at the Historical Research Office of the Institute of National Remembrance in Gdańsk. Her research interests focus on Ukrainian history and Polish-Ukrainian relations in the 20th century. E-m a il: joanna.karbarz-wilinska@ipn.gov.pl. 